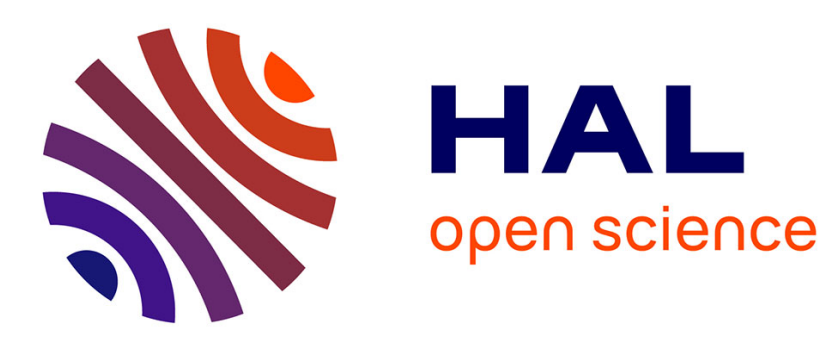

\title{
Loanwords in Kali'na, a Cariban language of French Guiana
}

Odile Renault-Lescure

\section{To cite this version:}

Odile Renault-Lescure. Loanwords in Kali'na, a Cariban language of French Guiana. Haspelmath, Martin \& Tadmor, Uri. Loanwords in the World's Languages A comparative Handbook, De Gruyter Mouton, pp.968-991, 2009. halshs-00714832

\section{HAL Id: halshs-00714832 https://shs.hal.science/halshs-00714832}

Submitted on 10 Jul 2012

HAL is a multi-disciplinary open access archive for the deposit and dissemination of scientific research documents, whether they are published or not. The documents may come from teaching and research institutions in France or abroad, or from public or private research centers.
L'archive ouverte pluridisciplinaire HAL, est destinée au dépôt et à la diffusion de documents scientifiques de niveau recherche, publiés ou non, émanant des établissements d'enseignement et de recherche français ou étrangers, des laboratoires publics ou privés. 


\title{
Loanwords in Kali'na, a Cariban language of French Guyana
}

\author{
Odile Renault-Lescure
}

\section{The language and its speakers}

The Kali'na (self-denomination) live in the north-east of South-America, in the vast regions of the Guianas. The Guianas Shield forms an "island" of approximately 1.800.000 $\mathrm{km}^{2}$ bordered by the Amazon River, the Negro River, the Casiquiare Canal, the Orinoco River and the Atlantic Ocean. It is constituted by the five Guianas: Venezuelan Guiana, (formerly British) Guyana, Suriname, French Guiana, and the state of Amapá in Brazil. The Kali'na represent a relatively important group with about 20.000 members distributed in these countries. 11.141 live in Venezuela, 3000 in Guyana (Forte 2000), 3000 in Suriname (Boven and Morroy 2000), about 4000 in French Guiana (Renault-Lescure 2003), and 28 in Brazil (ISA 2000). The number of speakers is lower, as in all countries the Kali'na communities have faced language loss, but this varies extremely from one place to another in the same country (30\% loss in Venezuela, $80 \%$ in Guyana, $50 \%$ in Suriname; there is no precise data for French Guiana, but the rate is high). The Kali'na people speak different dialects, one of which is the eastern variety, spoken by the Kali'na who call themselves Kali'na Tilewuyu, in the eastern part of Suriname and French Guiana. In French Guiana, a sub-dialectal frontier divides the speakers into a Western and an Eastern group. The Kali'na are spread out into various places of the region: They live in the indigenous municipality of Awala-Yalimapo and partially in other western or eastern villages: Village Javouhey, Terre Rouge, Village Pierre, Espérance, Paddock, Prospérité, Bellevue-Yanou, Village amérindien of Kourou, scattered settlements of Organabo, as well as in the western and eastern towns of Mana, Saint-Laurent, Cayenne and Kourou.

The Kali'na language, also known as Galibi in French Guiana, as Carib in Suriname and as Kari'ña in Venezuela, belongs to the Cariban language family. The most ancient attestation of a Cariban language is from the Kali'na language, the first to come in contact with Europeans. It is the Introduction à la langue des Galibis 
written by the Priest Pierre Pelleprat (1606-67). The first attempt to classify the Cariban languages was made by Salvatore Gillij (1721-89) for the Venezuelan languages. To date, there is no accepted internal classification of the Cariban languages. They have been treated quite differently in the three most recent classifications (Gildea 1998). Gildea's work in progress (2002) proposes three main branches: the Venezuelan branch, the Southern branch, and the North-Amazonian branch, plus some languages that do not belong to any of these branches, among them Kali'na.

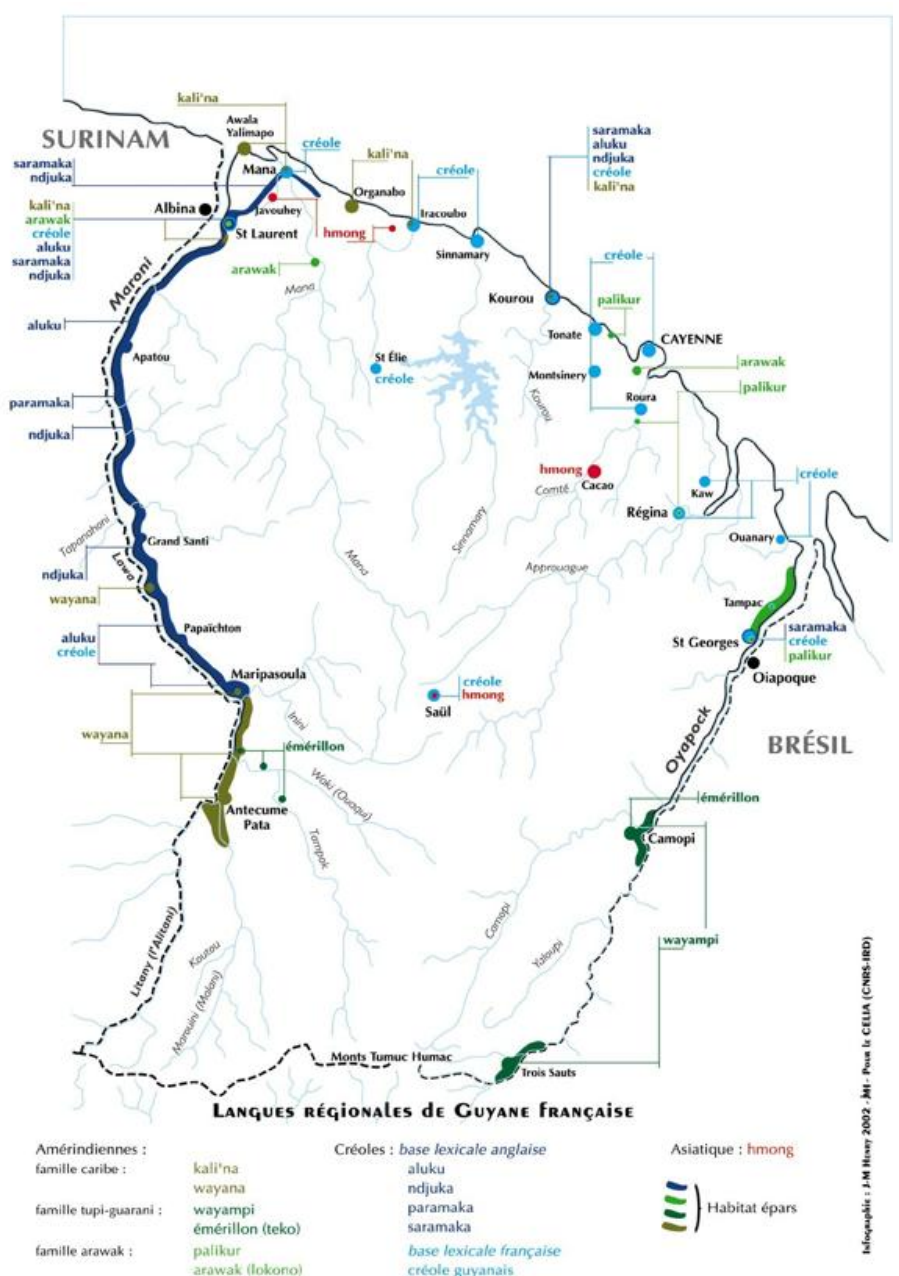

French Guiana is a French administrative entity (French Overseas Department). The official language is French and, since 2001, the indigenous languages are 
recognized as "Languages of France" defined as follows by the Délégation Générale à la langue française et aux langues de France (Ministery of Culture):

'The 'Languages of France' include the regional and minority languages that are traditionally spoken by French citizen on the territory of the Republic and are not official languages in any other country [...] These criteria of definition are inspired by the European Charter for regional or minority languages'.

Among the "Languages of France" in French Guiana, Guianese French Creole is the only "regional language", while the other languages (Amerindian languages, Maroon languages, and Hmong) remain minority languages. This status does not confer any linguistic rights, but recognizes the linguistic diversity of the French nation and allows these languages to benefit from some advantages.

Kali'na has the traditional vernacular uses in the families and villages. It is spoken almost exclusively by the Kali'na themselves, and its knowledge by outsiders is very exceptional. Its uses extended rapidly in the last decades of the 20th century and the beginning of the 21th in various unusual domains, especially in the indigenous municipality of Awala-Yalimapo, which was created as a separate administrative entity in 1989. There, it has entered into political speeches, administrative interactions (management of the municipality, post office), and in the primary school where the pupils have received a partial instruction in the Kali'na language since 1998.

The major religion, the Catholic church, does not make use of the native language in its practices, but the growing influence of evangelical missions that translate the bible into the vernacular languages is changing the linguistic landscape in religious contexts, especially in the villages where larger numbers of Surinamese live.

In the media, the language does not have a representative presence, but there are some local stations in the western part of the region where the people prefer to listen to a popular Surinamese Kali'na programme. No written media exist, other than some texts in a periodical published by some Kali'na people of Kourou. 
After a four-year process involving workshops bringing together native speakers, linguists and an anthropologist, an orthography was adopted by the community in 1997 giving birth to a chart known as "Déclaration de Bellevue". This writing system is used in the school for elaborating pedagogical materials. Some individuals are beginning to propose bilingual pieces of literature (myths, tales or poems) for bilingual publications (Renault-Lescure 2007). This orthography is used in the present work.

But the favourite area for using and spreading the language is music. Various musical associations exist, influenced by the creativity of the Kali'na of Suriname who mix traditional rhythms and songs, and contemporary music of the Caribbean.

Recent archaeological research shows that the Amerindian presence in the Guianas and the Amazon Region is very remote. 2000 B.C. is the beginning of an increasing number of settlements of sedentary farmers and the drawn of complex societies, testified by elaborate ceramics. Other waves of different populations, coming from the East $(+500)$ and later $(+1000)$ from the South occupied the Guyanese coast until the arrival of the Europeans (Restrain 2009+).

When Europeans initially established contact with the "savage coast" in the sixteenth century to trade goods, the territory that the Kali'na, estimated 5500 (Grenand \& Grenand 1979), shared with other peoples eventually became French and Dutch Guianas. At the end of the seventeenth century, weakened by new diseases and epidemics brought by more recent immigrants, the Kali'na began to forge new relationships with the now dominant colonial occupiers. Notwithstanding their demographic decline, the Kali'na nonetheless represented the most important Amerindian population between Cayenne and Paramaribo. Furthermore, their language became the lingua franca among Amerindians of different nations and the primary means of communication with the Europeans along much of the coast.

In the mid-nineteenth century, the number of Tilewuyu Kali'na living along the Maroni River dwindled to a few hundred. They lived in plots of land between French Guiana and Dutch Guiana that the Europeans had not yet exploited. However, colonization soon extended into these western areas and the Kali'na increasingly found themselves engulfed in a largely foreign-influenced environment. Their family- 
based economy became dependent on activities engendered by the colonial situation while their collective mobility became increasingly restricted. While their relations with other Amerindian groups grew more sporadic until, by the end of the nineteenth century, they found themselves interacting almost exclusively with foreigners and foreign-influenced populations: Europeans, Creoles, and Maroons from the Lower Maroni. Hence, economic domination and a social order stratified into "civilized" and "primitive" peoples defined the colonial environment surrounding the Kali'na. 


\section{Sources of data}

Lexical data for this research project were mainly taken from the earlier systematic work on loanwords in kaolin's Evolution lexical du galibi, langue caribe de Guyane by Renault-Lecture (1985). The lexicon contains 347 loanwords. This work was based on various sources. Because of its coastal distribution, Kali'na was in contact from an early date with European languages. It attracted the attention of the colonizers, particularly missionaries, who wrote the first sketches of its grammar and lexicon. The result of this attention is that documentation of the language dates as far back as the $17^{\text {th }}$ century. The first attempts to write grammatical sketches of Kali'na with lists of words and phrases date from this period. The first work is Bite's (1661) Les Galibis: Tableau véritable de leurs moeurs avec un vocabulaire de leur langue an accountof his journey in Guiana from 1652 to 1653. It contains a chapter De la langue galibi, followed by a lexicon with 400 words. In fact it describes a lingua franca used along the coast for evangelization and trade needs (Taylor \&Hoff 1980, Renault-Lescure 1984), but while the phrases are a description of a kind of "Pidgin Galibi", the word list is useful for lexical knowledge. The second work is Introduction à la langue des Galibis, Sauvages de la Terre ferme de l'Amérique méridionale written by Pelleprat, a missionary who was based on the Guarapiche river (in Venezuela today) from 1653 to 1654 , constitutes a document of thirty pages, out of which nineteen are devoted to grammatical observations and seventeen to a thematic lexicon. The other material consists of word lists collected by naturalists and traders. All these works were compiled by an agronomist (De la Salle de l'Estaing 1763) in a Dictionnaire galibi that does not give any new information. The next useful production appears with Les Etudes linguistiques Caraibes by de Goeje (1909). This important work adds new information based on de Goeje's own data from the eastern Kali'na variant and data compiled from colonial documents written in another language than French (Spanish, English, German, Dutch). It brings to our knowledge the first loanwords from the period called 'rise of Creoles'. Two main works from the $20^{\text {th }}$ Century, the Encyclopaedie der Karaiben by Ahlbrinck published in 1931 in Amsterdam, and The Carib language: phonology, morphonology, morphology, texts and word index by Hoff (1968) provide some additional information on loanwords. 
The other data used in Renault-Lescure (1985) come from my own fieldwork in the years 1979-1981. During my recent research (from 1998), I added new data and new ideas based current research in the area of language contact.

\section{Contact situations}

Table 1. Kali'na history of contacts (adapted from Rose and Renault-Lescure 2007)

\begin{tabular}{|c|c|c|c|}
\hline $\begin{array}{l}\text { Historical } \\
\text { phases }\end{array}$ & $\begin{array}{l}\quad \text { Main } \\
\text { contact } \\
\text { language }\end{array}$ & $\begin{array}{l}\text { Type of } \\
\text { contact }\end{array}$ & $\begin{array}{l}\text { Social contact } \\
\text { situation }\end{array}$ \\
\hline $\begin{array}{l}\text { 1) Pre- } \\
\text { Columbian } \\
\text { times }\end{array}$ & $\begin{array}{l}\text { Arawakan } \\
\text { Cariban } \\
\text { Tupi- } \\
\text { guarani } \\
\text { Languages } \\
\text { Other } \\
\text { Amerindian } \\
\text { languages }\end{array}$ & $\begin{array}{l}\text { direct and } \\
\text { indirect } \\
\text { intense }\end{array}$ & $\begin{array}{l}\text { ethnic alliances } \\
\text { and wars/ trade, } \\
\text { celebration and } \\
\text { marriage exchanges }\end{array}$ \\
\hline $\begin{array}{c}\text { 2) early } \\
\text { colonial times }\end{array}$ & $\begin{array}{l}\quad \text { Spanish } \\
\text { Portuguese } \\
\text { Dutch } \\
\text { French }\end{array}$ & $\begin{array}{l}\text { direct and } \\
\text { occasional } \\
\text { extinction } \\
\text { of the majority } \\
\text { of the } \\
\text { indigenous } \\
\text { languages }\end{array}$ & $\begin{array}{l}\text { first contacts/ } \\
\text { alliances and war or } \\
\text { slavery } \\
\text { technological and } \\
\text { political changes }\end{array}$ \\
\hline $\begin{array}{l}\text { 3) rise of } \\
\text { the Creoles }\end{array}$ & $\begin{array}{l}\text { Creoles } \\
\text { (Sranan } \\
\text { Guyanese) }\end{array}$ & $\begin{array}{c}\text { some } \\
\text { bilingualism }\end{array}$ & $\begin{array}{l}\text { Trade } \\
\text { contacts/social } \\
\text { networks with Creole } \\
\text { populations }\end{array}$ \\
\hline
\end{tabular}




\begin{tabular}{|c|c|c|c|}
\hline 4$)$ & French & intense \\
"Francisation" & & $\begin{array}{c}\text { political/governm } \\
\text { (widespread } \\
\text { bilingualism) }\end{array}$ & ent domination \\
& & schooling \\
\hline
\end{tabular}

\subsection{Amerindian language contacts}

Contact is ancient in the languages of the Guianas. Recent work in the field of ethno-history points to the complexity of the contact situation, due to the presence, the overlap and the mobility of numerous groups populating the area. Grenand \& Grenand (1979) point out that there were more than thirty different indigenous ethnic groups encountered by the first Europeans that landed on the Guianese coast during the $16^{\text {th }}$ century. The landscape of the pre-Colombian indigenous Guianas comprises ethnic groups in intense contact, with languages belonging to three main linguistic families, Cariban, Arawakan and Tupi-Guarani.

The lexicons of these unrelated languages share a lot of common elements, which represent, accordingly to the situations, mutual borrowings whose ancestry is generally difficult to trace. Even though we can clearly trace the Tupi-Guarani origin of the word alawe 'beetle, Periplaneta americana', or the Cariban origin of the word awala 'palm-tree, Atrocaryum vulgare Mart.', it is not possible to trace the origin of a lot of common words in Amazonian languages, such as kuwata 'spider-monkey, Ateles paniscus L.' (Renault-Lescure 2000).

\subsection{First contacts with European languages}

The arrival of the Europeans during the $17^{\text {th }}$ Century and the commercial trade left their mark. The Kali'na referred to contact goods with the words of the first Europeans they met. Borrowings are primarily from Spanish and Portuguese, and less commonly from English, Dutch and French. Despite the rapid settling of the French, there are surprisingly few early borrowings from French. This first stock of Kali'na borrowings were diffused and used all along the coasts of the Guianas, from the mouth of the Orinoco to Approuague, in eastern Guyana and after toward the 
south along the rivers. The indigenous southern languages in turn borrowed these words from Kali'na, or from the Kali'na-based lingua franca (e.g. Spanish arcabuz > Kali'na alakaposa 'rifle' > Wayana alakapuha, Wayampi alakausa).

During this period there was no situation of general bilingualism. Exchanges were carried out with the help of interpreters and through the use of a lingua franca with by a Kali'na lexicon (Taylor and Hoff 1980, Renault-Lescure 1984).

The $18^{\text {th }}$ century was a transitional period during which the Dutch and French colonies established themselves more firmly, creating the economic and political setting in which the Kali'na live until now. Contacts with European languages decreased, being replaced by contacts with languages that arose in the colonies with the slave trade and the construction of Creole and Maroon societies.

\subsection{Contact with creole languages}

\subsubsection{English -based creoles}

The numerous lexical borrowings from English-based creole languagess in the $19^{\text {th }}$ century do not have their origin in the first contacts with Maroon groups, the Aluku, speakers of an English-based creole, who had arrived some time before in the lower Maroni area. Instead, they show the privileged relationship of the Kalina with the Dutch colony, whose contact language was Sranan, another English-based creole. Kali'na speakers were often bilingual in Sranan until the end of the 20th century as a result of their history as refugees in the Dutch colony in the 18th and 19th centuries, as well as strong trade relations across the border. Knowledge of Sranan was strengthened by the arrival of Surinamese refugees after the civil war in Suriname in the 1980s. Sranan became a second language for the Kali'na, and in the last decades of the $20^{\text {th }}$ century, a third language after Guianese Creole. In certain western settlements, it has replaced the lost Kali'na.

\subsubsection{French-based creoles}

The economic and social recentralization of the Kali'na on the right bank of the Maroni and Mana into the French colony, which began in the middle of the $19^{\text {th }}$ 
century, is visible through the appearance of borrowings from Guianese French Creole, a French-based creole used by the slaves and later, after the end of slavery in 1848 , by a new Creole society. During this period and the $20^{\text {th }}$ century, Guianese French Creole (as well as other French-based creoles from the Caribbean introduced during the gold rush) was largely used as vehicular language in French Guiana. It played an important role in this usage among the Kali'na, who became bilingual. Some Eastern Kali'na of French Guiana, who were cut off from the Surinamese Kali'na, began to use Guianese French Creole as a first language, with loss of their original language. Kali'na speakers began to replace the loanwords from Sranan with borrowings from Guianese French Creole. This fact strengthened the dialect boundary between the western and the eastern varieties of the Kali'na language of French Guiana.

(1) western Kali'na kelege siwitisoli kalden eastern Kali'na

légliz 'church'

dilwil 'oil'

musike 'mosquito-net'

\subsection{New contact with French}

In the fourth phase, Guiana underwent the unification of its administrative system as a French department, and the settlement of French institutions such as administrative representations and schools (the first Kali'na children went to school in 1945). As a consequence, contact with French became more intense, tending to substitute the creole languages as a vehicular language nowadays. Today, bilingualism with French is widespread among Kali'na speakers, and for the great part of them the creole language has become the third language.

During the transition between the last periods, one observes a competition between the loanwords of creole origin and new borrowed forms of French origin. The transition ending frequently with the a case of replacement as, for example, 'shovel' borrowed from Sranan as sikopu and from Guyanese Creole as lapèl being sometimes replaced by the French pelle. 
So some loanwords from the creole languages continue to be used, especially those from Sranan, more ancient and firmly integrated, and reinforced by the immigration from Suriname, some of them disappear, but as the contact situations vary in time and space, there is no absolute rule. Nevertheless, French has been the most important language in contact with Kali'na in French Guiana since the second half of the $20^{\text {th }}$ century.

It is worthwhile to note that actually, those language contacts take place in a context of wider multilingualism. Migrations of the late $20^{\text {th }}$ century have triggered a rise of speakers of Surinamese English-based creoles, spoken by the Maroons (the Nenge(e) with its varieties Aluku, Ndyuka, Pamaka), as well as a rise of other languages as Haitian (French-based) Creole, and Brazilian Portuguese, Sranan, Dutch, English from the other Guianas.

\section{Number and kind of loanwords}

The Kali'na database contains 1672 entries, of which 313 are meanings without equivalent in this language. Of the remaining distinct words, there are 103 kali'na words that represent sub-counterparts, for example species of palm tree, or of monkeys, without meaning in the core list and a number of records adding words for common entities of the Amazonian indigenous environment and life. Other numerous words represent super-counterparts, such as nono 'land', 'earth', 'soil'. 1201 Kali'na items have no evidence of borrowing and 209 are probably (9) or clearly borrowed (200). Out of this set of loanwords, 80 items are of Sranan origin, 36 items of Guianese French Creole, 33 items of French origin, 27 items of Spanish origin, 9 items of Spanish or Portuguese origin, 6 items of Tupi-Guarani origin, 5 items of Dutch origin, 2 items of Portuguese origin, 1 item of presumed Arawak origin, and 1 item of Aluku (English-based creole) origin.

\subsection{Loanwords compared}

A comparison of loanwords by source language confirms the socio-historical scenario as described for the colonial period. The lack of sources and the complexity of the 
situation in pre-Colombian times do not give us a solid basis for comparing Amerindian loanwords. The greater part of the probable loanwords from these sources do not appear in the database, as they are part of a specific Amazonian lexicon with names of plants, animals and some basic vocabulary (Renault-Lescure 2005).

It is noteworthy that no contact language has an overwhelming presence in the borrowings. This fact may be correlated with the socio-linguistic situation in the first centuries of colonial times: sporadic direct or indirect contacts with European languages and the use of the Kali'na-based lingua franca as the primary means of communication with the Europeans. The demographic decline may have played a role too.

Loanwords from Spanish (or Portuguese), Dutch or French from the early colonial phase result from the first contacts with Europeans. As noted by Kloos (1971) "The impression the Spanish seafarers made on Amerindian must have been tremendous. Although the Spanish after only relatively few voyages made room for English and Dutch discoverers and traders, the impact of the first years of contact is still clearly evident in many words of Spanish origin in the Carib language". The narratives of the kali'na about the first contact with White people bear out the brutal shock and the importance of the goods such as the iron tools. First, they became essential to their basic activities and created a subordination to Europeans. Secondly, the Kali'na were implicated in the trade along commercial routes on the coast and into the interior of the Guianas.

Very numerous are the loanwords pertaining to the third phase ('rise of creoles'). The source languages of this period are Sranan (the most important language), and Guianese French Creole. The quasi-absence of loanwords from the English-based creole spoken by the Maroons is interesting but in fact not surprising. The Maroons had a prolonged association with the Kali'na, sharing the same environment. As the Maroon cultures adopted some Amerindian methods in exploiting the natural resources, the borrowings were made by the Maroon languages from the Amerindian languages. 
The relatively greater importance of borrowing from Sranan started during the second half of the $19^{\text {th }}$ century, period characterized by a general increase of contact with the European and creole populations of the French and Dutch colonies. New economic and social relations were established with two recent created little towns, Albina on the left bank of the Maroni and Saint-Laurent on the right bank, as a penitentiary. They became economic centers, with European products, attracting all the different groups of the Maroni River. Kloos (1971:10) reports:

"[...] Albina is almost a miniature of Surinam's plural society. It counts Chinese already since Kappler's time [1848 the foundation of the settlement], East Indians or Hindoustani, Javanese, Creoles, Dutch and strongly acculturated Amerindians among its inhabitants. Languages of all the people mentioned are spoken, although the creole language (Negro English, called Sranan by the sophisticated) is the lingua franca. The town is frequented by the Djuka and other Bush negroes, mainly from the upper and middle course of the Maroni, and by Waiyana from the upper reaches of the Maroni, the Litani and the Palumeu. Both groups have built their traditional houses in Albina. An Arowak village [...] forms part of the town [...] and tribal Caribs are daily visitors.[...] St Laurent, situated opposite Albina, shows the same picture, albeit on a larger scale."

Because of the status of the penitentiary of Saint-Laurent, and because Albina was more easily connected to Paramaribo and its European products, this town was frequented more by the Kali'na. It is noteworthy to remember that an important number of the Kali'na of the western part of French Guiana moved to Dutch Guiana during the period of the penitentiary. This situation explains clearly the numerous loanwords of Sranan origin.

The loanwords from Guianese French Creole correspond to a new colonial period beginning in the last decades of the $19^{\text {th }}$ century. The transformation of the western part of the region is due to three major phenomena. The first is the abolition of slavery (1848) and the progressive construction of a Creole society that spoke a French-base creole. The second one is the gold rush, especially on the Mana river, and the creation of the town of Mana that became an active commercial center. It attracted various populations, Creoles, Maroons, Chinese, Vietnamese, East Indians, mixed Brazilians, Arabs, each of them speaking its own language and using the French-based creole for communicating (Collomb 2000). The third phenomenon playing a major role in the growing influence of Guianese French Creole is the new 
social and economic settlement of the Kali'na people in the western part of French Guiana. Some villages came back from the Dutch colony, and the Kali'na villages already established in this area left their isolation from the rest of the colony. The Kali'na population established intense social relations with the Guianese Creoles later on, comparable in a certain way to the relations with the creoles of Suriname that were described earlier.

Loanwords from French correspond to the fourth ("new contact with French"). In 1946, the colony of "Guyane" became an overseas department, i.e. a territorial and administrative entity that is an integral part of the French nation.

\footnotetext{
"The transformation of French Guiana into a Department removed the colonial distinction between 'French citizen' an 'Indigenous people', but it was only in the beginning of the 1960s that the state has allotted French citizenship to the Amerindians. This was the first step towards a policy of cultural and social integration, by grouping previously isolated families and re-settling them into large villages, and by schooling of children within the framework of boarding schools managed by the Catholic clergy. Their integration into an expanded France had important economic and social effects by granting Amerindians the right to access the welfare system, which would eventually represent for these resettled families a new and important source of income, with consequences for Amerindian economies and social systems" (Collomb 2006)
}

As a consequence, contact with French became more intense and French is tending to replace the creoles as vehicular language nowadays. Contacts with the creoles are decreasing, and speakers' attitudes towards these languages are changing too. Mastering French is more or less seen as a key for social success (for work, studies, and involvement in the political and administrative structures).

These tendencies are still differentiated by the changes in the vehicular role assigned to the creole languages. The French Guyanese Creole that was largely attested in this function in all parts of French Guiana began to lose it. This is due to two reasons: the demographic decrease of the Creole population and the arrival of numerous speakers of English-based creoles on the western border of the country. In the region of Saint-Laurent, these creoles are replacing Guianese French Creole as vehicular language. So the contact situation is changing, influenced by new migrations. 


\subsection{Loanwords and semantic word class}

The table 2 presents a classification of loanwords according to their lexical class.

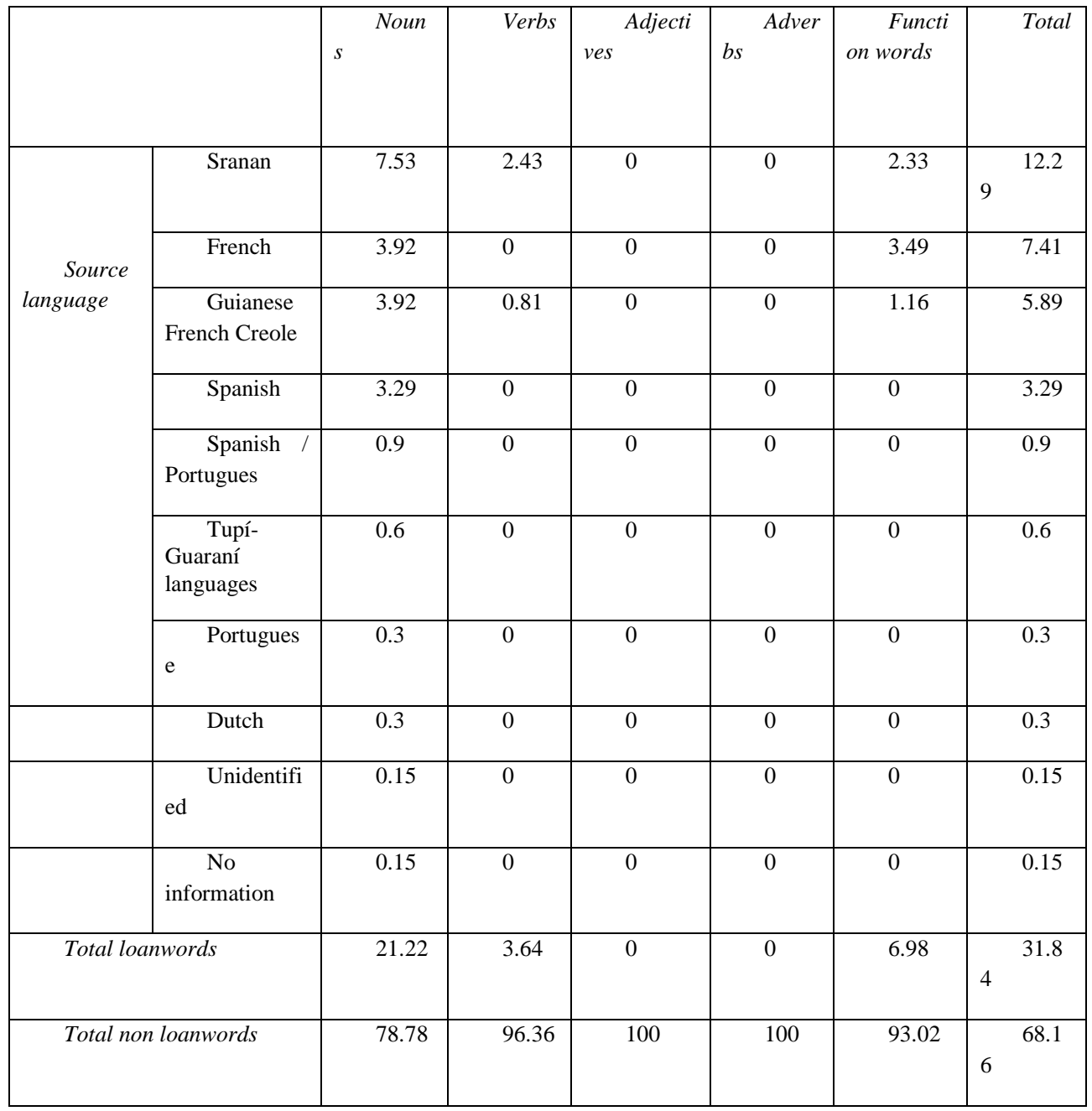

Table 2: Loanwords in Kali'na by semantic word class (percentages)

Kali'na differentiates only four major word classes: nouns, verbs, adverbs (playing the role of qualifiers once nominalized) and function words. All these words switch easily from one class to the other through derivational processes.

Nouns are by far the largest semantic word class represented, followed by function words and verbs. Among the list of loanwords present in the database, neither adverbs nor adjectives appear. 
Borrowed nouns, regardless of their source language and the period of borrowing, are integrated into the class of Kali'na nouns.

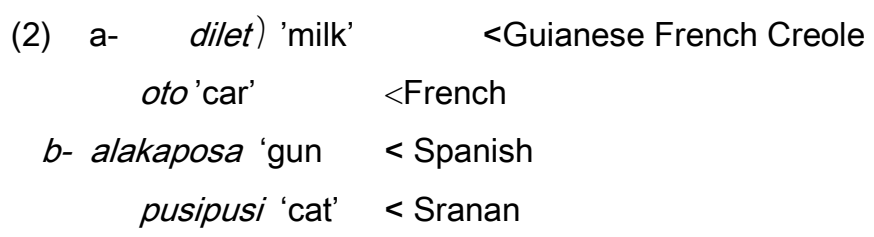

The vast majority of them fall into the sub-class of alienably possessed nouns category (a), while only a few fall into the sub-class of non-possessed nouns which have a suppletive form in the possessive construction - category (b):

(3)

$$
\underset{\text { alakaposa 'gun }}{\text { paila 'bow', }}\}
$$

kulewako 'parrot?

my cat'
O-ilapali 'my weapon, my 1-weapon-POSS

$$
y-e k \dot{t}
$$

'my pet, my parrot,

$$
\text { pusipusi 'cat' 1-pet-POSS }
$$

There are no instances of words being transferred into the sub-class of inalienably possessed nouns (kin terms, body parts, parts of a whole).

Loanwords that appear in the semantic class of function words are from the creoles and French. They consist of some conjunctions, especially from French (with the use of numerals).

Borrowings that appear in the semantic class of verbs are limited to the creole languages. The creole source languages offer examples of multifunctionality (Bruyn 2002). Some words function as noun, verb or adjective without any change in word class being morphologically marked. This ability seems to be quite common in Sranan, especially with forms used as a verb and as a noun, and less common in Guianese Creole.

\subsection{Loanwords and semantic field}


Table 2 presents the breakdown of loanwords in semantic fields. Certain semantic areas avoid borrowing, as 'mankind terms', 'parts of body' and 'sense perception' and others seem to be not permissive, as 'physical world', 'spatial relations' 'temperamental, moral and 'aesthetic notions' and 'law'. In these last domains, the Sranan is the more present donor language, followed by Guianese French Creole and French. In the semantic fields remaining with a low rate of loanwords such 'territorial, social, and political divisions, or 'Quantity and number' it is noteworthy that the more recent contact languages played a role, except in the fields 'Vocal utterance, speech, music' with the presence of the Spanish borrowing sanpula 'drum' that became the most important musical instrument in Kali'na culture, and 'warfare and hunting' with the introduction of firearms.

An increasing number of loanwords appears in two fields, attesting however various phases of contacts. 'Animals' shows a high rate of Spanish loanwords from the early colonial time. Among them only pelo 'dog' became a normal part of family life, the others remaining in the lexicon because the Kali'na knew about their existence, such as pïliku 'pig', paka 'ox, cow', kawale 'horse', paliko 'donkey', but they did not enter in the way of life of the Kali'na.

On the other hand, loanwords in the field 'time' predominantly originate from French, with the divisions of the calendar.

'Agriculture, vegetation', 'motion' or 'miscellaneous physical acts' presents comparable distributions of loanwords, the higher number from Sranan, moderate from Spanish (but with important domesticated plants as asikalu 'sugar cane') and a lower importance of Guianese French Creole or French.

An important Creole influence is found in the fields 'Food and drink; cooking and utensils' and dwelling, house furniture'. They result from the geographical and social proximity of the Creole societies when Kali'na came to visit, or some times to live in little towns where the Kali'na heard these languages as lingua francas and were shown housing practices in change.

The field 'clothing, personal adornment and care' contains loanwords from almost all languages, with particular influence of Spanish (general loanwords for cloth, dress and shoes), Sranan and French (more specific loanwords).

Finally, the most important field in terms of number of loanwords is the one of 'modern world', where an increasing number of loanwords from Guianese French 
Creole and French are observed. It attests a division between eastern and western Kali'na Tilewuyu's linguistic practices and induced by sociolinguistic contacts and a new pressure from the official languages of French Guiana and Suriname, where the influence of Dutch on Kali'na is similar to the influence of French on the other side of the border.

Some features are interesting to note across various semantic fields. For example, the influence of schooling and purchasing is obvious with the naming of days and numbers in French in 'time' and 'quantity and number'.

Another characteristic is the mapping of semantic fields. Ancient loanwords have acquired large semantic values, with various kinds of semantic changes: alakaposa 'gun' (from Spanish arcabuz) changes its meaning with the technological change, kaleta 'book, paper' acquired a lot of new referential values.

Kali'na borrowed essentially words relating to material items and other concepts associated with non-Indian products or practices by insertion. Co-existence is observed in the case of dialectal competition, and replacement of native words is rare. It appears nevertheless with the increasing number of French words inserted in today's speech.

\section{Integration of loanwords}

In this section, we deal first with the major processes that loanwords have undergone, independently of the origin of the language, except the Amerindian languages for which we do not know the source words.

All Spanish, Portuguese, Dutch, French (ancient loanwords) and early Sranan and Guianese French Creole borrowed words are fully assimilated to the phonological, morphonological and morphological patterns of Kali'na, while some Sranan and Guianese French Creole loanwords are partially integrated.

The phonological integration involves various processes of adaptation of the borrowed item, among them substitution of phonemes.

Although there is no opposition between $\mathrm{p} / \mathrm{b}, \mathrm{t} / \mathrm{d}$, and $\mathrm{k} / \mathrm{g}$ in Kali'na, the stops $/ \mathrm{p} /$, /t/ and /k/ have voiced allophones, except word initially. Initial voiced stops in loanwords were regularly replaced by the corresponding voiceless obstruents:

(4) pantila [pandi:'ra] 'flag' < Spanish bandera 


$$
\begin{array}{lll}
\text { paliki [pa:ri'gi] } & \text { 'bark' } & <\text { French barque } \\
\text { kalasi [kara:'çi] } & \text { 'glass' } & <\text { Sranan grasi }
\end{array}
$$

During the final phase of the 'rise of creoles' with introduction of loanwords maintaining a voiced stop word-initially, a new opposition emerged:

$$
\begin{array}{cl}
\text { (5) pali 'barrage' } \neq \text { bali 'barrel' < French barril } \\
\text { panki 'skirt' } \quad \neq \text { banki 'bank (seat)' < Sranan }
\end{array}
$$

Another characteristic of the phonological system of Kali'na is the palatalization of consonants after /i/ (except when followed by the same vowel) and of /s/ after and before this vowel. Phonological integration involves allophonic realizations:

(6) asikalu [açica:'ru] 'sugar-cane' < Spanish açucar

$$
\text { sikopu [çico'pu] 'shovel' < Sranan skopu }
$$

As for all phonological, this adaptation is beginning to show some loss:

(7) lopital [lopi'tal] 'hospital' < Guianese French Creole lopital

Kali'na has a phonological constraint that restricts consonant clusters. The source words often contain consonant clusters that are not allowed by Kali'na. Consonant clusters that violate the syllable structure constraints are broken up by the insertion of an epenthetic vowel between two consonants, or adding a final vowel:

$$
\begin{aligned}
& \text { (8) paliki 'bark' < } \quad \text { French barque } \\
& \text { sipunu 'spoen' < Sranan spun }
\end{aligned}
$$

The quality of epenthetic vowels is determined by progressive or regressive assimilation, or is by default a vowel prone to devoice $(\mathrm{i}, \mathrm{l})$ ).

It seems that Kali'na does not use simplification processes because it has a tendency to accept (and sometimes even favor) polysyllabic stems and words.

These rules do not apply to the most recent borrowings (from Creole or French) that preserve consonant clusters:

$$
\text { (9) kalden 'mosquito-net' < Sranan garden }
$$

The morphological integration of loanwords depends on historical factors, but also on the source languages. Kali'na clearly differs in structure from European languages, which are fusional, and creoles, which are isolating. 
All borrowed nouns enter in the morphological patterns of Kali'na nouns. The numerous processes of derivation with or without change of word class are very productive, as well as the semantic changes:

- semantic derivation

(14) winu-menpo 'a glass of vine' <Spanish/Portuguese vino/vinho'wine' vine-DIMIN

-derivation with transposition

(15) lakele-to 'to lock' < Guianese French Creole laklé 'key' key-TR.VERBALIZER

- derivation with transposition to adverb and semantic change of the loanword (a) followed nowadays by a new morphological regular transfer in the noun class with a new semantic change (b):

(16) (a) i-kaleta-pa 'without paper, without document'

$$
\text { PRIV-paper-PRIVATIVE.ADV < Spanish carta }
$$

(b) i-kaleta-p[a]in 'some one without document, in irregular situation

PRIV-paper-PRIVATIVE.ADV-NMLZ (French un immigrant en situation irrégulière, un "sans papier")

- possessive inflection

(17) a-serviette-i-lí [asebvjetili] 'your towel' $<$ French serviette 2-towel-i-POSS

Contrary to this flexible adaptation of borrowed nouns to the patterns of Kali'na nominal morphology, the verbs, like the adjectives, are borrowed by means of a transfer in new invariable sub-categories of nouns (Rose and Renault-Lescure 2007).

Borrowings from the Sranan verb/noun category are always integrated as uninflected nominal stems to which a verbalizing suffix is attached to form transitive verbs, carrying a person prefix and a tense suffix:

(10) tamusi si-begi-ma-e

God 1A-prayer-VERBALIZER-PRS

'I pray God' 
The Kali'na verb begima 'to pray' has its origin in the Sranan form begi 'to pray, prayer'. To this form is suffixed a regular Kali'na morpheme of transitive verbalization -ma. This regular strategy involves a creative adaptation process and conforms fully to Kali'na patterns of derivation. Thus Kali'na borrowed the Sranan verb/noun forms as nominal stem in fact, but kept their verbal meaning by using them in a verbal construction. Why is the Sranan verb, unspecified for valency, always used in a transitive construction? Many linguists agree that morphological adaptation and class assignment may be hindered when the recipient language has complex rules. It is the case with the verbal system of Kali'na that displays split intransitivity. One may think that this strategy permits to avoid the assignment of the borrowed verb to one of the verbal intransitive sub-classes, "active" or "stative". Some of these loanwords are kept in the lexicon of French Guiana Kali'na, some disappear. The notable fact is that this kind of formation stopped when borrowing verbs from Guianese French Creole began.

Borrowings from Guianese French Creole follow a similar strategy, but the result is a different construction. The invariable forms of the Creole verb follow another pattern. In order to be used as predicate, they need to be embedded in predicative structures involving nominalized verbs in a postpositional phrase with -poko 'busy with'.

The postpositional group functions in a single-participant copular construction:

$$
\begin{aligned}
& \text { (11) pentiré poko man } \\
& \text { paint busy.with 3s.COP.PRS }
\end{aligned}
$$

'He is painting.'

Nowadays an increasing number of such structures is invading Kali'na everyday interactions, with two noteworthy features, the use of a two-participant construction with the transitive verb ifl'to put' and the opening of this structure to any French verb in its infinitive form (Renault-Lescure 2005, Alby and Renault-Lescure 2009+):

$$
\text { (12) woto nettoyer poko s-i-ya }
$$

fish clea busy.with 1A-put-PRS

'I am cleaning the fish.' (lit. 'I am putting it out for cleaning.') 
In this case we observe a reanalysis of a verb form from the donor language to a nominal form without inflexion in the recipient language. In the sentence above, the postpositional phrase acquired a function of complement, the noun woto 'fish' being the object of the verb illi' 'to put'.

This open structure now lead the speakers to insert a lot of French verbs, frequently replacing native forms, as in the example (4). These cases do not appear in the database, nor do the cases of insertion of French adjectives. Adjectives underwent a similar transpoistion to the class of adverbs in Kali'na: they are inserted as nominal roots adverbialized by means of an adverbializer:

(13) rouge-me man

$<$ French rouge 'red' red-ADVB 3.COP

'it is red'

The large number of loan nouns in relation with the other semantic word classes seems due to various factors. One of them is the need to name new objects introduced by contact with other groups. While this need may be catered for by the creation of new words (neologisms) or the borrowing of lexical items, the use of either mechanism depends on the interpretation of the new entities. The White men in general were named palanakilt (a compound noun meaning 'spirits of the see'), and reinterpreted as new entities of the indigenous world. In turn, the different colonial peoples were differentiated with borrowings palansi[sin] 'French', pulutekesi 'Portuguese'... as the installation of the different colonies were perceived as a foreign socio-political organization. A lexical mechanism is regular: an object is named with a borrowed word, but parts of the object and activities made with described with native words: pila 'sail' from Spanish, and pila epi 'mast, support of the sail'), oto 'car' from French, oto untima 'to drive (a car)' (as 'to drive a canoe'). Another fact is the vitality of the derivational processes (see below) and the compound forms based on possessive phrases (a), nominalized postpositional (b), verbal (c) or adverbial groups (d) in this language. In certain cases, it led to the creation of lexicalized compound phrases: 
(8) (a)kawale 'horse' < Spanish cavallo

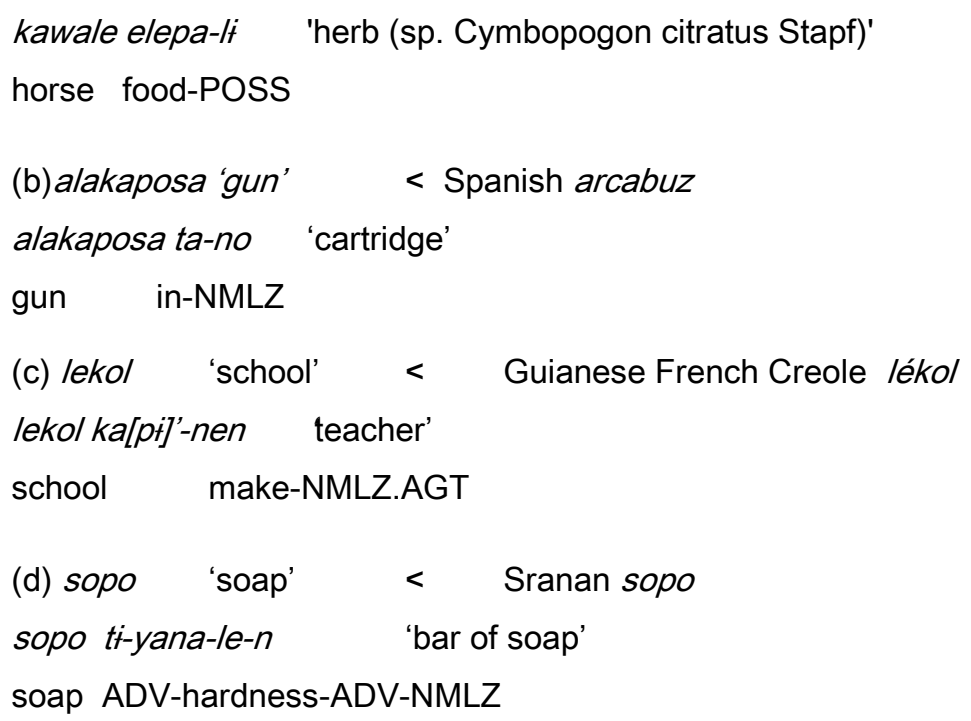

\section{Grammatical borrowing}

Direct grammatical borrowings are not observed, but syntactic changes in which contact may have triggered grammatical evolution are described in Rose and Renault-Lescure (2007).

Three contact-induced changes are worthy of notice. The first change is induced by the borrowing of a frequent functional word, the coordinative conjunction nanka 'and'(< Sranan) inserted between two nouns (cf. a). In the traditional Kali'na construction, a comitative postposition malo 'with' is postposed to the noun (cf. b):

a. wayamaka nanka akale

Iguana and Caïman

'Iguana and Caïman'

b. wayamaka akale malo

Iguana Caïman with

'Iguana with Caïman' 
The coexistence of the two constructions creates a significant typological change. Furthermore this conjunction is observed both as a coordinator between two phrases and two sentences.

Another change is linked to the borrowing of conjunctions. Kali'na is starting to replace its nonfinite subordination construction marked by postposed subordinators (such as yako 'when') with a finite subordinate construction introduced by a borrowed preposed subordinator, (such as paske 'because', < Guianese French Creole), which is very different from the inherited pattern, thus opening up the possibility of a typological change in subordination. But so far this change is restricted to these subordinate constructions with borrowed subordinators.

A third change is the reinforcement of analytical constructions being reinforced by the very frequent use of copular constructions and the construction with the verb $i t t$ 'to put' in order to integrate foreign verbs. The copula construction is now the exclusive way to integrate verbs from whatever language source into present-day Kali'na. Examples with Brazilian Portuguese as the source language have also been recently collected in Amapá, Brazil:

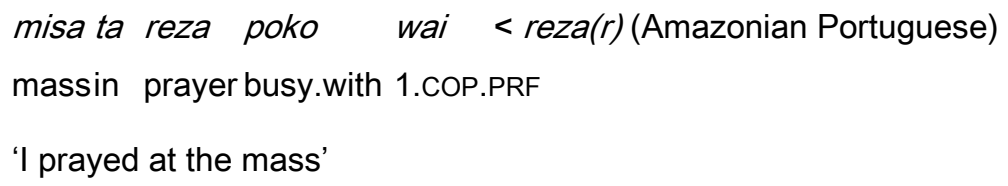

\section{Final remarks}

It seems worthy of notice that to understand Kali'na loanwords, we need to observe the different linguistic and sociolinguistic factors that play a role in this result of contact phenomena (Alby and Renault-Lecture 2009+).

\subsection{Linguistics factors}

-the relative timing of borrowed elements; the hierarchies of borrowablility predict that when contact is initiated, the first elements to be borrowed will be content items because they are the most salient and transparent of all potentially borrowable elements (Fields 2002). It seems particularly important to note that entities with 
visible referents are easiest to learn by speakers who have 'visibility' as a cognitive category, as it is the case with Kali'na;

-the impossibility of directly borrowing verbs when the verbal sytem of the recipient language is complex, or adjectives when the recipient language does not have the same word class; so there is a necessary reanalysis of the verbs from the source language to enter the Kali'na. In this language, relations between the arguments and the predicate are marked on the predicate with a person index, following a hierarchical system (Renault-Lescure 2002). We also noted the absence in the database of loanwords coming from an adjectival class in any source language: in the incipient borrowings of today, we showed that they are also reanalysed and integrated in an attributive sub-category of adverbs;

- the convergence between features of internal and external change: the Kali'na language today tends to use analytical sentence patterns (for example young people avoid to use nominal incorporation) and this fact seems parallel with the increasing use of auxiliary structures (for boworring verbs);

-the morphosyntactic changes triggered by loanwords as we have seen in the preceding section;

- the foreign items that are not directly borrowable are marked with specific morphemes. De Goeje (1946) gave the same meaning to the verbalizer -ma 'to apply, in the way of' and the adverbalizer -me 'in the way of'.

\subsection{Sociolinguistic factors}

-the intensity of contacts: three major waves of contact have left their mark on the language: violent contacts with the Spanish, contact with more social interaction with the Creoles in the 19th century, and contact with French with administrative and political pressure after the mid-twentieth century. It is interesting to remark that borrowings are sensitive to political and economical domination. That is the case for the Kali'na with a double minority situation in relation with the Creole and French societies. This may explain why the conviviality with Maroon peoples, disregarded, did not result in borrowings from these languages; 
-the attitudes of the speakers and the social context of interactions have an important part. Altough some 'purist' speakers are careful with the use of loanwords, this attitudes differs from one to other, following various parameters as the origin of the village and family, level of multilingualism, presence of foreigners, etc. but the use of borrowings is completely generalized. In addition, today the path for incipient or nonce-borrowings or insertions is opened and each speaker has various registers for using in various situations. Alby (2006) writes about Kalina '[...] language contact has led to numerous lexical changes and the question of whether language contact has brought about morphosyntactic change is still unresolved. Nonetheless, language games, alternations, bilingual speech as a code among adolescents (Alby 2003), with identity-building and cryptic functions, are signs of vitality in that the language is alive and functional language as a linguistic resource (Mondada 2002) for young speakers who, as the first generation attending secular schools, and experiencing the difficuties of drops in status and the creation of social outcasts (Collomb 2001).'

\section{Conclusion}

Kali'na has been in contact with different languages since pre-Colombian times. Apart from Amerindian languages, not well identified, seven different main languages left imprints on the lexicon, the influence of each of them being different following the type of the language in contact, its social dominance or minority situation, the intensity of the contact and the speakers attitudes. The present-day configuration is facing new contacts situations, characterized by the diversity of the situations and linguistics practices. Other languages in presence, a higher level of multilingualism, particularly bilingualism with French, the new permissiveness to alternate different codes. The loanwords have played a role with the high level of integration of nouns in the lexicon and the deployment of morphosyntactic mechanisms to insert all kind of word classes.

\section{Abbreviations}

*1 first person /*2 second person /*3 third person /*A agent-like argument of canonical transitive verb /ADV adverb(ial) /*AGT agent, agentive /*COP copula /*DIMIN diminutive 
/*NMLZ nominalizer/nominalization /*P patient-like argument of canonical transitive verb /*POSS possessive /*PRS present /*S single argument of canonical intransitive verb

\section{References}

Ahlbrinck, Wilhelmus G. 1931. «Encyclopaedie der Karaïben ». Verhandelingen der

Kon. Akademie van Wetenschappen, afd. Lett., XXVII. XIV + $555+160$ pp. (1956.

Encyclopédie des Caraïbes, traduit du néerlandais par Herwijnen, Doude van, Mis en forme : Police :(Par défaut) Arial Unicode MS, 12 pt, Français manuscrit dactylographié).

Alby, Sophie. 2001. Contacts de langues en Guyane française: une description du parler bilingue kali'na-français. Thèse de doctorat de I'Université de Lyon II.

Alby, Sophie \& Renault-Lescure, Odile. 2009+. « Stratégies prédicatives en contact. Langue kali'na et discours des jeunes Kali'na » in Chamoreau, Claudine and Goury, Laurence (eds.) Changement linguistique et langues en contact: approches plurielles du domaine prédicatif.

Biet, Antoine. 1896. " Les Galibis: Tableau véritable de leurs moeurs avec un vocabulaire de leur langue (1661) », Rem. et publié par Aristide Massé, Revue de Linguistique, juillet/octobre, Paris.

Boven, Karin and Morroy, Robby. 2000. «Indigenous Languages of Suriname », in Queixalòs, Francisco and Renault-Lescure, Odile (eds) As línguas amazônicas hoje, São Paulo: IRD-ISA-MPEG: 377-384.

Boyer, Paul, sieur de Petit Puy. 1654 Véritable relation de tout ce qui s'est fait et passé au voyage que $M$. de Bretigny fit à l'Amérique occidentale, Paris: P. Rocolet. 
Bruyn, A. 2002. 'The structure of the Surinamese Creoles' In Carlin, Eithne B. and Arends, Jacques (eds.), Atlas of the Languages of Suriname, KITLV Press, 153-182.

Carlin, Eithne B. 2004. A Grammar of Trio. A Cariban Language of Suriname. Duisburger Arbeiten zur Sprach- und Kulturwissenschaft 55. Berlin: Peter Lang.

Collomb, Gérard and Tiouka, Félix. (with participation of Appolinaire, Jean and Renault-Lescure Odile). 2000. Na'na Kali'na. Une histoire des Kali'na en Guyane, Petit Bourg, Guadeloupe: Ibis Rouge Editions.

Collomb, Gérard. 2006. « Disputing Aboriginality: French Amerindians in European Guiana » in Forte, Maximilian C. (ed.) Indigenous resurgence in the contemporary Caribbean: Amerindian survival and revival, NY: Peter Lang: 197-212.

Field Fredric W. 2002. Linguistic Borrowing in Bilingual Contexts. Amsterdam/Philadelphia: John Benjamins Publishing Company.

Forte, Janette. 2000. «Amerindian Languages of Guyana » in Queixalós, Francisco and Renault-Lescure, Odile (eds) As línguas amazônicas hoje, São Paulo: IRD-ISAMPEG: 317-331

Gildea, Spike. 1998. On Reconstructing Grammar, Comparative Cariban Morphosyntax. New York/Oxford: Oxford University Press.

Gildea, Spike. 2002. «Etat de l'art des descriptions linguistiques des langues du groupe caribe », in Landaburu, Jon and Queixalós, Francesc (eds.) Faits de Langue: Méso-Amérique, Caraïbes, Amazonie vol. 2: 79-85

Gildea, Spike and Doris Payne. 2007. « Is Greenberg's Macro-Carib viable? Lingüística Histórica na América do Sul », Ana Vilacy Galucio and Pieter Muysken (eds). Boletim do Museu Emilio Goeldi, Série de Ciências Humanas. Belém: Museu Goeldi.

de Goeje, Claudius.H. 1909. "Etudes linguistiques caraïbes ». Verh. D. Kon. Ak; v. Wet. Afd. Lett. n.r. X n 3 , Amsterdam. 
Grenand, Pierre and Grenand, Françoise. 1979. «Les Amérindiens de Guyane française aujourd'hui. Eléments de compréhension». J.S.A. 66:361-382.

Hoff, Berend.J. 1968. The Carib language, phonology, morphonology, morphology, texts and word index, Martinus Nijhoff, The Hague.

Instituto Socio-Ambiental, 2008, A Enciclopédia dos Povos Indígenas no Brasil, http://www.socioambiental.org/prg/pib.shtm

Léglise, Isabelle and Alby, Sophie. 2006. "Minorization and the process of (de)minorization: the case of Kali'na in French Guiana ». Int.J.Soc.Lang. 182: 67-85.

Renault-Lescure, Odile. 1984, "A propos des premières descriptions d'une langue caribe, le Galibi », in Auroux, Sylvain and Queixalós, Francesc (eds.) Amerindia n spécial 6:183-208.

Renault-Lescure, Odile. 1985. Evolution lexicale du galibi, langue caribe de Guyane française, Paris, TDM ORSTOM, F 16.

Renault-Lescure, Odile. 1990. "Contacts interlinguistiques entre le karib et les créoles des côtes guyanaises », Etudes Créoles, vol.13, n²: 86-93.

Renault-Lescure, Odile. 2002. «As palavras e as coisas do contato. Os neologismos Kali'na (Guiana Francesa) " in Albert, Bruce and Ramos, Alcida Rita (orgs.) Pacificando o Branco. Cosmologias do contato no Noerte-Amazônico, São Paulo: Editora UNESP: 85-112.

Renault-Lescure, Odile. 2005. "Intégration grammaticale des emprunts et changements linguistiques dans la langues kali'na de Guyane française (famille caribe) ». In Chamoreau, Claudine \& Lastra, Yolanda (Eds.) Dinámica lingüística de las lenguas en contacto, Universidad de Sonora: 103-120.

Renault-Lescure, Odile. 2007. «L'écriture du kali'na en Guyane. Des écritures coloniales à l'écriture contemporaine» in Léglise, Isabelle and Migge, Bettina (eds.) Pratiques et représentations linguistiques en Guyane. Regards croisés, Paris, IRD éditions: 425-453. 
Renault-Lescure, Odile 2009+a. "Guyana Francesa » in Sichra, Inge (ed.) Atlas etnográfico y sociolingüístico de Latinoamérica y El Caribe. UNICEF / FUNPROEIB.

Renault-Lescure, Odile 2009+b. "Guyana Francesa » in Sichra, Inge (ed.) Atlas etnográfico y sociolingüístico de Latinoamérica y El Caribe. UNICEF / FUNPROEIB.

Renault-Lescure, Odile and Goury, Laurence. 2009+. Les langues de Guyane, La Roque d'Anthéron: Vents d'Ailleurs/IRD.

Rose, Françoise and Renault-Lescure, Odile. 2007. «Contact-induced changes in Amerindian Languages of French Guiana», in Romancisation world-wide, T. Stolz, R. Salas Palomo and D. Bakker (eds), Mouton de Gruyter: 349-376.

Salle de l'Estaing, M. de la. 1763. «Dictionnaire galibi, présenté sous deux formes: I $^{\circ}$ Commençant par le mot français; $I^{\circ}$ par le mot galibi. Précédé d'un essai de grammaire», in Bruletout de Préfontaine, Maison rustique à l'usage des habitants de Cayenne. Paris: Bauche: 1-127.

Taylor, Douglas. M. and Hoff, Berend. J. 1980. «The linguistic repertory of the IslandCarib in the seventeenth century: the men's language-a Carib pidgin? ", International Journal of American Linguistics 46: 301-312. 